\title{
The Exploration of the Advantages and the Drawbacks of Private English Education in China
}

\author{
Mingjun Yang \\ The University of Melbourne,473000
}

Keywords: English private education, China, Advantages, Drawbacks

\begin{abstract}
Alongside the tendency of globalization and more communication with the world, learning English for Chinese people is not only only about the original purposes of taking English examinations for accessing higher education or professional titles, but also for some multiple purposes, such as learning English for studying abroad, traveling overseas, working with foreigners. In this situation, Chinese traditional public English educational pattern focusing on grammatical learning and English examinations cannot satisfy the various English learning needs of Chinese people anymore in modern Chinese society. However, it is extremely difficult to achieve Chinese nation-wide public English education innovation to satisfy an increasing number of English learning needs of Chinese people in a short time. To comply the demands of more targeted English learning from Chinese people and to remedy the deficiency of current Chinese traditional public English education, more and more private English educational organizations have established in China, especially in some well-developed cities, such as Shanghai, Beijing. These private English educational organizations usually conduct their English education in small-sized class, even one-to-one class. Furthermore, compared with Chinese traditional public English education system, the English teachers of these private organizations are not only Chinese people majored in English, but also English native-speakers from English-speaking countries. Nevertheless, even though the organizations indeed can provide the English learners with more flexible and advanced English learning strategies and better educational resources, the private English education is still immature in China. Since there are not national standards to regulate the various private English educational organizations in China, the qualities of these organizations are patchy. This study would focus to explore the advantages and drawbacks of current Chinese private education and provide some professional suggestions to make the English private education more efficient and rational in China.
\end{abstract}

\section{Literature Review}

\section{The Development of English Education in China}

Systematic English education in China started from $19^{\text {th }}$ century, the late Qing Dynasty. Alongside the arrival of missionaries from the western countries, English was taught in some missionary schools in China (Zhang, 2016). The main purposes of English education at that time were to deliver western religious thoughts and to popularize western religions. Very a few Chinese people could access English education at that time. With the collapse of Qing Dynasty, China started to have more communication with the world, especially with England and the USA who had advanced thoughts and technologies. English was no longer a language for religious purpose; it was educated as a communicative tool in Chinese universities even middle schools to help the students to experience advanced knowledge from some well-developed countries. In the early $20^{\text {th }}$ century, the English education systems for Chinese universities and middle schools were gradually established, which benefited more and more Chinese people especially the youth to have a chance accessing English education.

After the establishment of the People's Republic of China in 1949, the development of English education is full of twists and turns in China. In 1950s, Russian replaced English as the first choice for Chinese people to learn as a foreign or second language because of the close political relationship between the governments of China and the Soviet Union. During the Great Cultural Revolution, the quality of Chinese English education dropped by a large margin ( $\mathrm{Li}, 2001$ ). Alongside the end of the Great Cultural Revolution and the implementing of economic reform and 
opening-up policy in 1979, both government and Chinese people realized the importance of English education again. Chinese Ministry of Education gradually revised public English syllabuses in different levels; English education became more standardized and efficient to some extent. At the same time, rather than universities and middle schools, English courses were introduced to Chinese public primary schools. Children have obvious biological and social advantages to acquire languages (Schumann, 2013). As a consequence, introducing English to public primary schools is not only good for improving the universality of Chinese public English education, but also facilitates to exploit Children's advantages to achieve more efficient English acquisition. As for Chinese individuals, good English proficiency benefits Chinese individuals' further study and career because of the tendency of globalization. Up to now, Chinese people regard English competence as one of the most important personal competences promoting individual development. Furthermore, an increasing number of Chinese people would like to acquire English as a bridge to experience a wider world.

\section{Private English Education in China}

Due to the large number of population and a vast territory, as well as various customs, it is very difficult to make common-used Chinese public English education syllabuses to satisfy increasing English learning needs of Chinese people in diverse aspects. In an addition, Chinese traditional public English education in primary schools, middle schools and universities pays more attention to English examinations rather than English communicative competences for the sake of accessing better schools and institutes. Both English teachers and students always ignore English communicative competences due to this exam-oriented educational pattern. Meanwhile, because of Chinese large population base and the limits of English educational resources, traditional public English class in China usually utilizes fixed textbooks and inflexible teaching strategies; beyond that, the class size also is large, it is very common that there are more than 40 students in a traditional public English class with only one English teacher. Therefore, even though one of important Chinese national public educational policies is that the content of education should be useful and helpful for everyone (Chen, 2010), it is impossible for traditional public English education achieving high-quality English education to satisfy the various needs of students.

In this situation, private English education organizations have been developing rapidly in China in order to remedy the deficiency of Chinese traditional public English education. Especially in some well-developed cities, such as Beijing and Shanghai, these cities as the earliest open-up cities have more chances to approaching international organizations and foreigners. The English learning needs in these cities are not only about English examinations, but also communicating with people from other countries benefitting for further study, career and business. Most of private English educational organizations hire English teachers from English-speaking countries to teach learners to use English with more native-like speaking accent and appropriate speaking ways. Besides, small-sized even one-to-one English class pattern is utilized in most of private English educational organizations, which is conducive to provide the English learners with specific teaching and learning strategies in accordance of their aptitudes and specific needs. As the obvious advantages of English private education mentioned above, it is rapidly developed in recent decades and widely accepted by Chinese people from different areas. However, on account of Chinese private English education is still in the developing stage, the systems and the national standards are not mature. Many negative problems have been revealed during the development of Chinese private English education. This study would focus on exploring the advantages and drawbacks of current Chinese private English education and providing with professional suggestions to relevant stakeholders to make the private English teaching and learning more efficient and rational.

\section{Advantages of English Private Education in China}

Alongside the rapid development of Chinese economic and the tendency of globalization, Chinese people are fronted with more complicated multicultural social backgrounds and linguistic diversity. Cross-cultural or transcultural communication becomes more and more common in daily life. English as a most-used global language plays an essential role in the tendency of globalization. 
Compared with Chinese traditional public English education, private English education pays more attention to English communicative competences rather than examination competences, which contributes to make English as a communicative tool assisting Chinese people to have easier communication with various people from different countries and regions. Gardener (2011) indicates that language learner' adaptation and attitudes significant influence on the outcomes of language acquisition. Private English educational organizations in China usually utilize more flexible teaching strategies taking a full account of individuals' diverse attitudes towards English and adapting abilities. Therefore, focusing on English for communicative tool in daily life and teaching students in accordance of their different personal circumstances such as attitudes is one of special strategies compared with traditional public English education in China, which makes private English education more efficient and targeted.

Rather than special teaching strategies, the educational resources of private English education are much more sufficient than traditional public English education in China. Since the tuition fees of Chinese private English educational organizations are usually very expensive, the organizations have sufficient funding to get sufficient English educational resources, such as advanced educational facilitates, overseas professional textbooks and materials. Besides, private English educational organizations always utilize small-size even one-to-one class to teach English, which ensures that every learners' needs and demands can be immediately realized by the English teachers and the teachers can teach English according to the learners' personal circumstances. More than that, sufficient funding supports the private English educational organizations to hire plenty of English native-speakers from English-speaking countries. Even though some public schools hire English-native speakers as English teachers, the number of them is very small; it is very difficult to let every student get adequate English education from these foreign teachers. Meanwhile, in public schools, most of English teachers are Chinese nationality majored in English, English for these teachers are the second language not the mother tongue, so they may not teach the students with native-like accents and authentic western educational concepts. Introducing more foreign teachers who are native-speakers makes the private English educational organizations be more competitive and brings higher quality English education. To some extent, sufficient educational resources especially the increasing number of English native-speaking teachers are the key for Chinese private English education to achieve success.

\section{Drawbacks of Private English Education in China}

Although Chinese private English education develops rapidly in recent decades and benefits more and more Chinese people accessing higher quality English education, it is still immature because it only has been developing since 1980s. National standards of Chinese private English education have not been officially established yet. The government and the Ministry of Education do not have powerful regulatory means to control the market of private English education. The qualities of different private English educational organizations are extremely various. Even some private English educational organizations do not have appropriate English teaching qualifications. Besides, compared with public English education system, the process of introducing foreign teachers in private English educational organizations is irregular. To cut down expenditures, some unscrupulous private English educational organizations hire the foreign teachers without any educational backgrounds. More terrible thing is that a few organizations hire foreign teachers from Russia, Ukraine and other non-English speaking countries; these foreign teachers only have western appearances, but their English proficiency is not enough to be an English teachers. Hiring these foreigners as English teachers can be regarded as faking the English learners. Therefore, establishing normative national standards and regulatory system to normalize Chinese private English educational organizations is very urgent.

Another main drawback of private English education in China is unreasonable expensive tuition fee. Different from Chinese public English education, private English education in China means unaffordable English education. The price of a short-term private English educational course usually is at least thousands Chinese RMB, even more than ten thousands Chinese RMB. As for 
long-term private English educational courses, the amount of tuition fee is unimaginable. Therefore, most of Chinese ordinary people cannot afford private English education; private English education becomes luxurious thing in Chinese society. Besides, the range of tuition fee is wide depending on different private English educational organizations. The prices of similar courses in different organizations are significant different. Expensive tuition fees and irregular charges more or less limit the sound development of private English education in China.

\section{Discussion and Conclusion}

Private English education has been rapidly developing since 1980s, after the end of Chinese Cultural Revolution and the start of Chinese Economic Reform and open-up policy. In the past decades, private English education significantly influences on the improvement of English education in China. Traditional Chinese public English education pays much more attention to English examinations for the sake of accessing higher education. Moreover, Chinese pubic English education is similar to most traditional language educational system concentrating on inflexible grammatical learning and reciting (Kenny, 2011). By comparison, Chinese private English education utilizes more flexible and innovative teaching strategies, as well as focuses on English for use rather than English for test. Furthermore, it is not doubtable that private English education usually has more educational resources due to sufficient funding. Hence, private English education can remedy the deficiency of Chinese public English education and provides better strategies and resources to both educators and learners for the sake of more efficient language acquisition. Therefore, insisting the development of Chinese private English education and encouraging more professional English educators and learners involved in private English education in the future is very necessary.

In the meantime, because of short developing history of Chinese private English education, it is still immature due to deficient national standards and unsound regulatory system. Moreover, irrational expensive tuition fees and chaotic payment standards make a majority of Chinese people unwilling to accept private English education as an efficient way to learn English. Besides, irregular system of introducing foreign teachers also negatively impacts the quality of private English education in China. Therefore, to substantially improve the quality of Chinese private English education in all aspects, the most vital thing is establishing reliable national private English educational standards and efficient regulatory system to control teaching quality. Apart from this, both the government and the private English educational organizations should emphasize on the private English teachers' screening and evaluation, high-quality teachers is the fundamental of high-quality education. As for the problem of tuition fee, the relevant departments in-charge such as the Ministry of Education can measure the educational quality and resources of Chinese private English educational organizations and divide them into different levels. These departments may give guidances of appropriate tuition fee range for the private English educational organizations according to their levels and locations. Appropriate tuition fee of Chinese private English education contributes to attract more and more English learners to access high-quality private English education and benefit the improvement of Chinese private English educational industry.

\section{References}

[1] Chen, G. (2010). Chongxin Renshi Yingyu he Yingyu Jiaoyu de Diwei [Re-acquaintance of the Statuses of English and English Education]. Foreign Language Teaching and Research, 42(4), 291-293.

[2] Garden, R. C. (2011). The Socio-educational Model of Second Language Acquisition. Canadian Issues / Thèmes Canadiens, 2011, 24-27.

[3] Kenny, L. A. (2011). Doing Students Justice: How First Language Acquisition Influences Second Language Acquisition. Illinois Reading Council Journal, 39(4), 10-14.

[4] Li, X. (2001). Woguo Yingyu Jiaoyushi Chutan [The Initial Exploration of Chinese English Educational History]. Journal of Qingdao Ocean Shipping Mariners College, 22(3), 24-31. 
[5] Schumann, J. H. (2013). Societal Responses to Adult Difficulties in L2 Acquisition: Toward an Evolutionary Perspective on Language Acquisition. Language Learning, 63(1), 190-209.

[6] Zhang, D. (2016). Zhongguo Yingyu Jiaoyu de Fazhan yu Weilai [The Development and Future of Chinese English Education]. Contemporary Foreign Languages Studied, 2016(1), 14-22,30. 